\title{
Occurrence of anthropogenic and naturally-produced organohalogenated compounds in tissues of Black Sea harbour porpoises
}

\author{
Liesbeth Weijs $^{\mathrm{a}, \mathrm{b}, *}$, Krishna Das ${ }^{\mathrm{c}}$, Hugo Neels ${ }^{\mathrm{a}}$, Ronny Blust ${ }^{\mathrm{b}}$, Adrian Covaci ${ }^{\mathrm{a}, \mathrm{b}}$ \\ ${ }^{a}$ Toxicological Centre, University of Antwerp, Universiteitsplein 1, 2610 Wilrijk, Belgium \\ ${ }^{\mathrm{b}}$ Laboratory of Ecophysiology, Biochemistry and Toxicology, Department of Biology, University of Antwerp, Groenenborgerlaan 171, 2020 Antwerp, Belgium \\ ${ }^{\mathrm{c}}$ Laboratory for Oceanology-MARE Centre, University of Liège, 4000 Liège, Belgium
}

\section{A R T I C L E I N F O}

\section{Keywords:}

Harbour porpoise

Black Sea

Anthropogenic compounds

Naturally-produced compounds

Tissue distribution

\begin{abstract}
A B S T R A C T
Harbour porpoises are one of the three cetacean species inhabiting the Black Sea. This is the first study to report on polybrominated diphenyl ethers (PBDEs) and naturally-produced compounds, methoxylated PBDEs (MeO-PBDEs) and polybrominated hexahydroxanthene derivatives (PBHDs), in tissues (kidney, brain, blubber, liver, muscle) of male harbour porpoises (11 adults, 9 juveniles) from the Black Sea. Lipid-normalized concentrations decreased from muscle $>$ blubber $>$ liver $>$ kidney $>$ brain for the sum of polychlorinated biphenyls (PCBs) and for the sum of PBDEs. Among the naturally-produced compounds, levels of PBHDs were higher than of MeO-PBDEs, with tri-BHD and 6-MeO-BDE 47 being the dominant compounds for both groups, respectively. Concentrations of naturally-produced compounds decreased from blubber to brain, similarly to the sum of DDT and metabolites (DDXs). Concentrations of DDXs were highest, followed by PCBs, HCB, PBHDs, PBDEs and MeO-PBDEs. Levels of PCBs and PBDEs in blubber were lower than concentrations reported for harbour porpoises from the North Sea, while concentrations of DDXs were higher.
\end{abstract}

(c) 2009 Elsevier Ltd. All rights reserved.

\section{Introduction}

Polychlorinated biphenyls (PCBs) and polybrominated diphenyl ethers (PBDEs) are two groups of lipophilic anthropogenic compounds which are banned in Europe since the 1970s (PCBs) and in 2004 and 2008 (PBDEs). PCBs and PBDEs were used in electrical devices, textiles, furniture and other household products, foams and plastics (ATSDR, 2001, 2004; Birnbaum and Staskal, 2004). Both groups of pollutants consist of 209 different congeners, which differ in the number and the position of the chlorine or bromine atoms, respectively. The biochemical and physical characteristics are therefore different for each congener, thereby influencing their fate, distribution and toxicity in wildlife and in the environment. As a result, PCBs and PBDEs are still present in ecosystems (Ruus et al., 1999; Boon et al., 2002; Borgå et al., 2004; Johnson-Restrepo et al., 2005; Burreau et al., 2006). In these systems, concentrations of PCBs and PBDEs tend to biomagnify throughout food chains, ultimately reaching high levels in tissues of top predators (Ruus et al., 1999; Boon et al., 2002; Johnson-Restrepo et al., 2005). Marine mammals are situated at the top of their food chains and accumu-

\footnotetext{
* Corresponding author. Address: Laboratory of Ecophysiology, Biochemistry and Toxicology, University of Antwerp, Groenenborgerlaan 171, Building U, 5th Floor, 2020 Antwerp, Belgium. Tel.: +32 326535 41; fax: +32 32653497.

E-mail address: liesbeth.weijs@ua.ac.be (L. Weijs).
}

late considerable amounts of chemicals in their bodies causing adverse or toxic effects.

Besides PCBs and PBDEs, hexachlorobenzene (HCB) and pesticides ( $p, p^{\prime}$-DDT, $p, p^{\prime}$-DDE, $p, p^{\prime}$-DDD, $o, p^{\prime}$-DDT, $o, p^{\prime}$-DDE and $o, p^{\prime}-$ DDD) are well known anthropogenic pollutants. HCB was formerly used as a fungicide, but its production and use have been banned globally after the discovery of its carcinogenic nature and its high toxicity in aquatic organisms (ATSDR, 2002). Organochlorine pesticides, such as DDT and its metabolites (DDE and DDD), are proven to be beneficial for controlling insects in agriculture and also for preventing malaria. Although OCPs were once widely used, nowadays, they are banned in most regions of Europe and North-America. Yet, some OCPs are still in use in a number of countries surrounding the Black Sea (East-Europe) (Fillmann et al., 2002), in Asia and in South-America.

Recently, attention has been drawn towards the presence of naturally-produced compounds, such as methoxylated PBDEs (MeO-PBDEs) and polybrominated hexahydroxanthene derivatives (PBHDs) in aquatic ecosystems (Melcher et al., 2007; Covaci et al., 2008; Weijs et al., 2009b; Pena-Abaurrea et al., 2009). MeO-PBDEs can biomagnify in the food chains, acting in the same way as the anthropogenic PBDEs (Kelly et al., 2008; Losada et al., 2009; Weijs et al., 2009b).

Next to short-beaked common dolphins (Delphinus delphis ponticus) and bottlenose dolphins (Tursiops truncatus ponticus), 
harbour porpoises (Phocoena phocoena relicta) are one of three cetaceans inhabiting the Black Sea (Birkun, 2003; Tonay et al., 2007). Porpoises from the Black Sea are currently classified as 'endangered' (IUCN Red List of Threatened Species, 2008) as they suffer from habitat loss, accidental entanglement in fishing gear and pollution with metals and organic compounds (Madhusree et al., 1997; Tanabe et al., 1997a,b; Joiris et al., 2001; Birkun, 2003; Das et al., 2004). The Black Sea acts as a sink for chemicals as it receives high loads of pollutants through run-off from the surrounding countries and because it is linked to the Mediterranean Sea only through the Marmara Sea (Tanabe et al., 1997a). As a consequence, porpoises from the Black Sea are isolated from their counterparts in other European waters, migrate only on a small scale and spend their entire life in the same area (Fontaine et al., 2007; Viaud-Martinez et al., 2007).

To our knowledge, this is the first study to report on anthropogenic and naturally-produced brominated compounds in tissues of harbour porpoises from the Black Sea. The aims of this study were to discuss levels and profiles of anthropogenic and naturally-produced compounds in harbour porpoises from the Black Sea and to investigate the distribution of these pollutants between tissues in these animals.

\section{Materials and methods}

\subsection{Samples, chemicals and target compounds}

Blubber, liver, muscle, kidney and brain samples were collected from 20 male harbour porpoises (Phocoena phocoena; 9 juveniles and 11 adults) stranded or bycaught in the Black Sea in 1998 (Fig. 1). In all samples, 39 PCB congeners (IUPAC numbers: CB 18, $28,31,44,47,49,52,74,87,95,99,101,105,110,118,128,132$, $138,146,149,151,153,156,158,170,171,172,174,177,180$, 183, 187, 194, 195, 196/203, 199, 203, 205, 209), 8 PBDEs (IUPAC numbers: BDE $28,47,49,99,100,153,154,183)$, DDXs (o, $p^{\prime}-$
DDD, $o, p^{\prime}$-DDT, $o, p^{\prime}$-DDE, $p, p^{\prime}$-DDD, $p, p^{\prime}$-DDE, $p, p^{\prime}$-DDT) and HCB were targeted. In addition, two naturally-produced methoxylated PBDEs (2'-MeO-BDE 68 and 6-MeO-BDE 47), together with triBHD and tetra-BHD were investigated. Standards were from Wellington Laboratories (PBDEs and MeO-PBDEs), from Dr. Ehrenstorfer Laboratories (PCBs) and a gift from Walter Vetter (PBHDs).

\subsection{Sample preparation}

The method used for the sample extraction and clean-up has been previously described (Covaci et al., 2008) and is briefly presented below. Approximately $2 \mathrm{~g}$ of liver and brain, $0.2 \mathrm{~g}$ of blubber and $3 \mathrm{~g}$ of muscle and kidney were dried with $\sim 8 \mathrm{~g}$ anhydrous $\mathrm{Na}_{2} \mathrm{SO}$, spiked with internal standards BDE 77/BDE 128 (25 ng) and CB 143 (100 ng) and extracted for $2 \mathrm{~h}$ by hot Soxhlet with $100 \mathrm{ml}$ hexane/acetone $(3 / 1 ; v / v)$. After lipid determination (performed on an aliquot of the extract), the extract was cleaned on $8 \mathrm{~g}$ of acidified silica. After elution of analytes with $20 \mathrm{ml}$ hexane and $15 \mathrm{ml}$ dichloromethane, the cleaned extract was evaporated to dryness and reconstituted in $150 \mu$ iso-octane.

\subsection{Analysis}

PBDEs, MeO-PBDEs and PBHDs were measured with an Agilent 6890 gas chromatograph coupled with a 5973 mass spectrometer system (GC-MS). The GC was equipped with a $30 \mathrm{~m} \times 0.25$ $\mathrm{mm} \times 0.25 \mu \mathrm{m}$ DB-5 capillary column. The MS was operated in electron capture negative ionisation (ECNI) mode and was used in the selected ion-monitoring (SIM) mode with ions $m / z=79$ and 81 monitored during the entire run. PCBs, HCB and DDXs were measured with a similar GC-MS system as for the PBDE determination, operated in electron ionisation (EI) mode and equipped with a $25 \mathrm{~m} \times 0.22 \mathrm{~mm} \times 0.25 \mu \mathrm{m}$ HT-8 capillary column (SGE, Zulte, Belgium). The MS was used in the SIM mode with two ions monitored

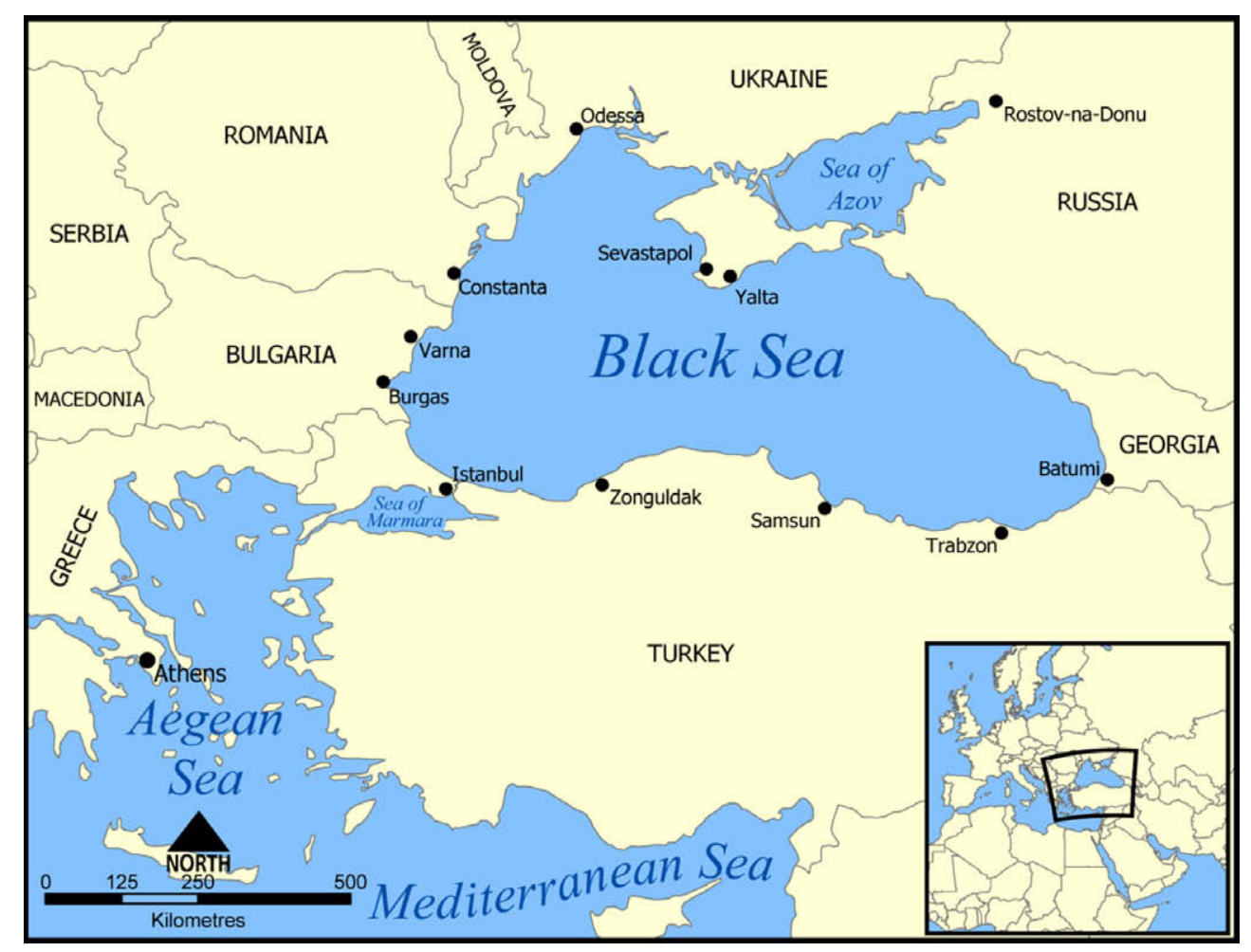

Fig. 1. The Black Sea - map of the study area. Source: climatelab.org/Bucharest_Convention 
for each PCB homologue group. The latter system (GC-EI/MS) was also used for confirmation of organobromine compounds.

\subsection{Quality assurance/quality control (QA/QC)}

Recoveries for individual PBDE congeners were between $87 \%$ and $104 \%$ (RSD $<12 \%$ ), while recoveries of PCBs ranged between $75 \%$ and $90 \%$ (RSD < 10\%). For each analyte, the mean procedural blank value was used for subtraction. After blank subtraction, the limit of quantification (LOQ) was set at three times the standard deviation of the procedural blank, which ensures $>99 \%$ certainty that the reported value is originating from the sample. For analytes that were not detected in procedural blanks, LOQs were calculated for a ratio $\mathrm{S} / \mathrm{N}$ equal to 10 . LOQs depended on the sample intake and on the analyte and ranged between 1 and $4 \mathrm{ng} / \mathrm{g}$ lipid weight (lw). QC was performed by regular analyses of procedural blanks, by random injection of standards and solvent blanks. A standard reference material SRM 1945 (PCBs and PBDEs in whale blubber) was used to test the method accuracy. Obtained values were not deviating more than $10 \%$ from the certified values. The QC scheme is also assessed through regular participation to interlaboratory comparison exercises organised by the US National Institute of Standards and Technology.

\subsection{Statistical analysis}

Statistical analyses were conducted using the SPSS 15.0 statistical package. The level of statistical significance was defined at $p<0.05$. For concentrations below the LOQ a value of $1 / 2$ LOQ was used. Outliers in all groups were detected by making boxplots. Non-parametric statistical tests were used since the data were found to have a non-normal distribution (Shapiro Wilk's statistical test). Differences in the concentrations and profiles of PCBs and PBDEs were compared between the two age-groups (adult males and juvenile males) using Kruskal-Wallis. Spearman's correlation coefficients were calculated using GraphPad Prism 4 (GraphPad Software, Inc.).

\section{Results}

\subsection{Lipids}

Lipid percentages ranged in general from $1.97-4.93 \%$ for kidney, 7.80-18.5\% for brain, $2.64-5.54 \%$ for liver, $0.22-7.33 \%$ for muscle and $87.6-97.3 \%$ for blubber in the present study. Concentrations discussed here are all lipid-normalized.

\subsection{Levels and profiles of PBDEs}

BDE 183 could not be detected in any sample, while BDE 47 was the most dominant PBDE congener in all samples representing between $50 \%$ and $72 \%$ of total PBDEs. Profiles were consistent among adults, with BDE $47>$ BDE $100>$ BDE $99>$ BDE 154 in all tissues. In contrast, there was some variation in juveniles with BDE 100 and 99 switching places depending on the type of tissue. Similar to sum PCBs, levels of sum PBDEs decreased from muscle to blubber, liver, kidney and brain (Table 1). No age influence was found as there were no significant differences in sum PBDEs (or any individual PBDE congener) between adults and juveniles in all tissues (all $p>0.05$ ).

\subsection{Occurrence of naturally-produced organobromines}

Tri-BHD, tetra-BHD, 2'-MeO-BDE 68 and 6-MeO-BDE 47 were targeted in the present study. Among MeO-PBDEs, 6-MeO-BDE
Table 1

Medians (range) expressed in ng/g lipid weight (lw) for sum PCBs, sum DDXs, HCB, sum PBDEs, sum MeO-PBDEs and sum PBHDs in tissues of harbour porpoises from the Black Sea.

\begin{tabular}{|c|c|c|c|c|}
\hline & $N$ & Adults & $N$ & Juveniles \\
\hline \multicolumn{5}{|l|}{ Sum PCBs } \\
\hline Kidney & $10^{\mathrm{a}}$ & $4044(2723-8739)$ & 9 & $3384(1851-7429)$ \\
\hline Brain & $10^{\mathrm{a}}$ & $1614(897-2282)$ & 9 & $1009(758-1575)$ \\
\hline Liver & $10^{\mathrm{a}}$ & $8450(4161-20,131)$ & $8^{a}$ & $6508(5311-13,532)$ \\
\hline Muscle & $9^{\mathrm{b}}$ & $17,420(9908-24,956)$ & $8^{a}$ & $11,707(8479-15,022)$ \\
\hline Blubber & 11 & $13,215(8810-24,875)$ & 9 & $6956(4896-13,665)$ \\
\hline \multicolumn{5}{|l|}{ Sum PBDEs } \\
\hline Kidney & $10^{\mathrm{a}}$ & $15.9(10.6-27.1)$ & 9 & $18.4(11.0-63.2)$ \\
\hline Brain & $10^{\mathrm{a}}$ & $3.1(2.4-5.5)$ & 9 & $3.9(2.1-6.2)$ \\
\hline Liver & $10^{\mathrm{a}}$ & $44.7(20.0-59.9)$ & $8^{a}$ & $44.0(30.8-66.3)$ \\
\hline Muscle & $9^{b}$ & $80.8(54.1-115)$ & $8^{a}$ & $80.4(48.0-102)$ \\
\hline Blubber & 11 & $65.6(43.2-85.1)$ & 9 & $57.0(47.5-72.8)$ \\
\hline \multicolumn{5}{|l|}{ Sum DDXs } \\
\hline Kidney & $10^{\mathrm{a}}$ & $13,643(9085-35,706)$ & 9 & $10,987(9474-20,116)$ \\
\hline Brain & $10^{\mathrm{a}}$ & 4821 (2682-9149) & 9 & $2921(1803-4401)$ \\
\hline Liver & $10^{\mathrm{a}}$ & $28,022(14,808-85,864)$ & $8^{a}$ & $20,053(16,055-48,934)$ \\
\hline Muscle & $9^{\mathrm{b}}$ & $75,821(42,258-100,858)$ & $8^{a}$ & $42,964(31,675-54,377)$ \\
\hline Blubber & 11 & $77,329(54,993-156,750)$ & 9 & $40,891(27,387-81,709)$ \\
\hline \multicolumn{5}{|l|}{$H C B$} \\
\hline Kidney & $10^{\mathrm{a}}$ & $521(408-572)$ & 9 & $393(275-655)$ \\
\hline Brain & $10^{\mathrm{a}}$ & $185(144-217)$ & 9 & $114(93-226)$ \\
\hline Liver & $10^{\mathrm{a}}$ & $1456(976-1848)$ & $8^{a}$ & $972(507-2107)$ \\
\hline Muscle & $9^{\mathrm{b}}$ & $823(633-1356)$ & $8^{a}$ & $518(332-875)$ \\
\hline Blubber & 11 & $575(487-926)$ & 9 & $394(298-774)$ \\
\hline \multicolumn{5}{|c|}{ Sum MeO-PBDEs } \\
\hline Kidney & $10^{\mathrm{a}}$ & $10.6(7.6-19.9)$ & 9 & $11.7(9.9-44.9)$ \\
\hline Brain & $10^{\mathrm{a}}$ & $2.3(0.6-5.6)$ & 9 & $3.1(2.2-7.0)$ \\
\hline Liver & $10^{\mathrm{a}}$ & $18.2(11.6-35.7)$ & $8^{a}$ & $21.7(16.9-61.6)$ \\
\hline Muscle & $9^{\mathrm{b}}$ & $39.0(20.8-72.8)$ & $8^{a}$ & $45.7(21.4-122)$ \\
\hline Blubber & 11 & $46.6(30.7-73.1)$ & 9 & 52.9 (44.9-79.9) \\
\hline \multicolumn{5}{|l|}{ Sum PBHDs } \\
\hline Kidney & $10^{\mathrm{a}}$ & $212(139-445)$ & 9 & $230(95-618)$ \\
\hline Brain & $10^{\mathrm{a}}$ & $36.2(16.9-53.7)$ & 9 & $32.5(20.8-55.9)$ \\
\hline Liver & $10^{\mathrm{a}}$ & $743(318-1444)$ & $8^{a}$ & $599(504-1324)$ \\
\hline Muscle & $9^{\mathrm{b}}$ & $1502(1003-2497)$ & $8^{a}$ & $1341(831-1963)$ \\
\hline Blubber & 11 & $2204(1535-3538)$ & 9 & 1509 (945-2206) \\
\hline
\end{tabular}

a One sample was not available.

b Two samples were not available.

47 was the most dominant compound. Tri-BHD had the highest concentrations for PBHDs and for all naturally-produced organobromines in total. Although concentrations of sum MeO-PBDEs were lower in adults compared to juveniles, no statistical significant differences were found for the sum MeO-PBDEs between adults and juveniles in all tissues (all $p>0.05$ ), except for brain (median concentrations of 2.3 and $3.1 \mathrm{ng} / \mathrm{g} \mathrm{lw}$ for adults and juveniles, respectively $(p=0.041)$ ). Levels of sum PBHDs were higher in adults than in juveniles, although only they were statistically different for concentrations in blubber (median concentrations of 2204 and $1509 \mathrm{ng} / \mathrm{g} \mathrm{lw}$ for adults and juveniles, respectively $(p=0.004))$. In addition, the highest concentrations of sum PBHDs and of sum MeO-PBDEs were found in blubber, while the lowest concentrations were in brain.

\subsection{Levels and profiles of PCBs}

Concentrations of sum PCBs decreased from muscle $>$ blubber $>$ liver $>$ kidney $>$ brain (Table 1 ). In all tissues and in both age-groups (adult males and juvenile males), CB 153 was the predominant congener (17-21\% of sum PCBs), followed by CB 138 and CB 149. For adults, CB 99 was the fourth congener as abundance, replaced by $C B 118$ in juveniles. The next congeners were $C B 95$ or CB 180 , depending on the age-group and on the tissue. CB 31 could only be detected in some brain samples. No differences were 
found for the sum PCBs between the adults and the juveniles in kidney, brain and liver (all $p>0.05$ ), while significant differences were found in blubber (medians of 13,215 and $6956 \mathrm{ng} / \mathrm{g}$ lw in adults and juveniles, respectively $(p=0.003)$ ) and muscle (medians of 17,420 and $11,707 \mathrm{ng} / \mathrm{g} \mathrm{lw}$ in adults and juveniles, respectively $(p=0.016))$.

\subsection{Levels and profiles of DDXs and HCB}

Results for HCB and sum DDXs ( $o, p^{\prime}$-DDT, -DDE, -DDD and $p, p^{\prime}-$ DDT, -DDE, -DDD) show that, for both age-groups, HCB levels were highest in liver, while sum DDXs were highest in blubber. Brain had the lowest concentrations of HCB and DDXs (Table 1). Significant age-related differences for HCB were found in all tissues, except in kidney, while concentrations of sum DDXs differed significantly between adults and juveniles in brain (medians of 4821 and $2921 \mathrm{ng} / \mathrm{g} \mathrm{lw}$ in adults and juveniles, respectively $(p=0.024)$ ), in muscle (medians of 75,821 and $42,964 \mathrm{ng} / \mathrm{g} \mathrm{lw}$ in adults and juveniles, respectively $(p=0.003)$ ) and in blubber (medians of 77,329 and $40,891 \mathrm{ng} / \mathrm{g}$ lw in adults and juveniles, respectively $(p=0.002)$ ). Among DDXs, $p, p^{\prime}$-DDE and $p, p^{\prime}$-DDD were the most dominant compounds, contributing to more than $90 \%$ to the sum DDXs. $o, p^{\prime}$-DDE represented the DDX compound with the lowest concentration in all animals.

\section{Discussion}

To our knowledge, the present study is the first to report on the levels of PBDEs and naturally-produced brominated compounds (MeO-PBDEs and PBHDs) in marine mammals from the Black Sea. The Black Sea represents a semi-enclosed area, linked to the Mediterranean Sea only through the Marmara Sea (Fig. 1). The Black Sea receives high loads of pollutants through run-off from the surrounding countries, from which some are still using banned/restricted POPs, and is of great economical importance for the people inhabiting these countries (Fillmann et al., 2002).

\subsection{Distribution between tissues}

The highest lipid percentages were consistently found in blubber, while the lowest percentages could be detected in kidney and muscle. The lipid percentages of each tissue seemed to be consistent, since no statistically significant differences were found between adults and juveniles. Lipid results from the present study were also comparable to those from other studies. Lipid percentages in porpoises analysed by Kannan et al. (1993), Tanabe et al. (1997a) and Berge et al. (2004) fall, in general, well in the ranges reported in the present study. Duinker et al. (1989) analyzed harbour porpoises from the North Sea between 1977 and 1979 and found percentages ranging from $1.4 \%$ to $6.7 \%$ for kidney, $5.3-$ $13.9 \%$ for brain, $2.1-8.6 \%$ for liver, $0.5-7.9 \%$ for muscle and $54.2-$ 93.5\% for blubber.

Due to differences in the function and in the lipid percentage between tissues and in the biochemical properties of the pollutants, the distribution of the chemicals may vary significantly in the animal's body. For sum PCBs and sum PBDEs, concentrations were higher in muscle, followed by blubber, liver, kidney and brain, respectively. Some PCB and PBDE congeners are highly lipophilic and are therefore primarily stored in blubber, which explains the high levels of PCBs in blubber. For similar reasons, PCB and PBDE concentrations in kidney were relatively low. Brain tissue often has a higher lipid percentage than muscle, liver and kidney. However, most likely due to the blood-brain barrier, concentrations of chemicals are usually lower than levels in any other tissue investigated in the present study (Bernhoft and Skaare, 1994).
For the sum MeO-PBDEs, sum PBHDs and the sum DDXs, blubber had the highest concentrations, followed by muscle, liver, kidney and brain, respectively. These compounds are lipophilic, naturally-produced (MeO-PBDEs and PBHDs) or still in use (DDT), which increases their bioaccumulative potential. For HCB, a different pattern was found with the highest concentrations in liver followed by muscle, blubber, kidney and brain respectively. The distribution of all investigated compounds remained the same in both age-groups (adults and juveniles), suggesting that partitioning between tissues is not changing over time or with age.

\subsection{Levels and profiles}

CB 153 and BDE 47 were predominant among PCBs and PBDEs, respectively. This is a typical and well known finding, not only in several marine mammal species (e.g. Covaci et al., 2002; JohnsonRestrepo et al., 2005; Ikonomou and Addison, 2008; Shaw et al., 2008, 2009; Montie et al., 2009; Weijs et al., 2009a), but in various fish species (Voorspoels et al., 2003, 2004; Johnson-Restrepo et al., 2005; Shaw et al., 2009) as well. CB 153 was followed by CB 138 and CB 149, which is different from PCB profiles in pinnipeds (Weijs et al., 2009a), but similar to the profile in harbour porpoises from the North Sea (Weijs et al., 2009a) and again very specific for harbour porpoises. Due to bioaccumulation with age and a reduced metabolism of some PCB congeners, levels of sum PCBs were consistently higher for adults than for juveniles in each tissue, although these differences were only statistically significant for muscle and blubber. In contrast, levels of sum PBDEs in kidney and brain of juveniles were higher compared to the levels in adults. The higher concentrations of sum PBDEs in brain in particular, are of concern, since the juvenile stage is an important time period in the development of the brain and for the animal in general. Profiles of PCB and PBDE congeners may differ in both age classes, probably due to an age-related potential for metabolism or a slow elimination of some congeners received from the mother during gestation or lactation (Debier et al., 2003a,b).

To enable comparisons with previous reports, the ratio of each of the seven PCBs (IUPAC numbers 28, 52, 101, 118, 138, 153 and 180), proposed by the International Council for the Exploration of the Sea (ICES) to CB 153 was calculated for the liver and blubber of harbour porpoises from the Black Sea and the North Sea (data of liver and blubber from Covaci et al. (2002) and Weijs et al. (2009a), respectively; Fig. 2). Higher ratios of lower chlorinated PCBs for both liver and blubber were found in the Black Sea porpoises, compared to the North Sea counterparts. This might be due to the historical use of different Aroclor mixtures in both areas. CB 180 is present in a higher proportion in Aroclor 1260 whereas CBs 101, 118 and 138 are indicative for Aroclor 1254 (Thompson et al., 1996). Although CB 153 is the predominant congener in this study and in other studies conducted in the North Sea (Covaci et al., 2002; Weijs et al., 2009a) and the ratios of CB 180 and CB 138 to CB 153 are similar in both areas, the higher ratio of CB 101 and CB 118 to $C B 153$ in the Black Sea might be indicative for a higher use of PCB mixture Aroclor 1254 in the Black Sea area compared to the North Sea.

Levels of PCBs and PBDEs in blubber and liver were lower than concentrations reported for harbour porpoises from the North Sea (Covaci et al., 2002; Weijs et al., 2009a) and were also lower than levels of PCBs measured in blubber of adult males from the Black Sea in 1993 (Tanabe et al., 1997a). This is the first study to report on PBDEs in harbour porpoises from the Black Sea, therefore, there are no results of PBDEs in Black Sea marine mammals to compare with. Overall, PBDEs had only a minor contribution in the animals (Fig. 3), suggesting that PBDEs were not consistently used before 1998 in countries surrounding the Black Sea. 


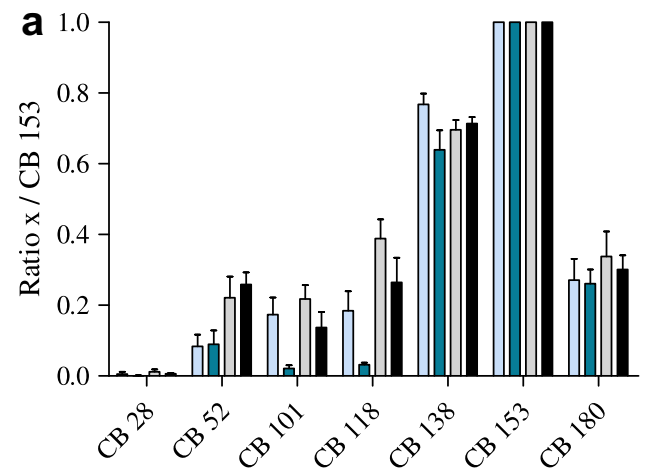

- Juveniles, North Sea

- Juveniles, Black Sea

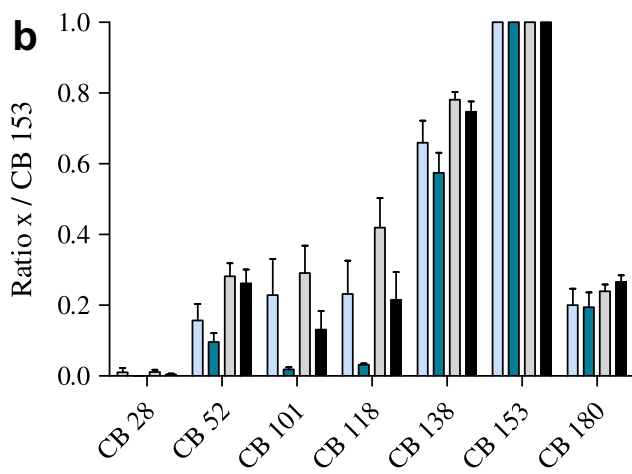

- Adults, North Sea

- Adults, Black Sea

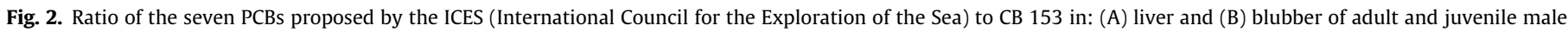
harbour porpoises from the North Sea (data of liver and blubber from Covaci et al. (2002) and Weijs et al. (2009a), respectively) and Black Sea (present study).



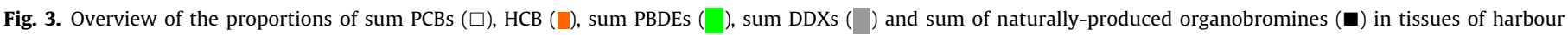
porpoises from the Black Sea.

For DDXs, the $p, p^{\prime}$-metabolites ( $p, p^{\prime}$-DDE and $p, p^{\prime}$-DDD) had the highest concentrations among all DDXs and in all tissues, while $o, p^{\prime}$-DDE had the lowest levels. Higher contributions of the $p, p^{\prime}$ DDX metabolites were previously also found by Montie et al. (2009) in cerebellum grey matter and cerebrospinal fluid of Atlantic white-sided dolphins, by Covaci et al. (2002) in liver of harbour porpoises, and by Hoekstra et al. (2003) in blubber of bowhead whales, beluga whales, ringed seals and bearded seals. Increasing concentrations of $p, p^{\prime}$-DDE and decreasing concentrations of $p, p^{\prime}-$ DDT can be explained by a higher metabolism of DDT in marine mammals relative to their prey together with the bioaccumulation of DDT metabolites, as suggested by Hoekstra et al. (2003). Concentrations in adults were, in general, higher than in juveniles, indicating bioaccumulation over time. The highest concentrations found by Hoekstra et al. (2003) for sum DDXs were reported in blubber of beluga whales with an average of $1979 \pm 231 \mathrm{ng} / \mathrm{g} \mathrm{lw}$ (mean and standard error, SE), which is more than 39 and 21 times lower than levels in blubber of adult and juvenile harbour porpoises from the present study. Also, concentrations of sum DDXs exceed by far the concentrations found in liver of harbour porpoises from the North Sea $(3.4 \pm 2.3 \mu \mathrm{g} / \mathrm{g}$ lw (mean \pm SD; Covaci et al., 2002). Considering an average lipid percentage of $90 \%$ in blubber of harbour porpoises from the Black Sea, concentrations reported in Tanabe et al. (1997b) were $77,800 \mathrm{ng} / \mathrm{g}$ lw for male porpoises (adult and juvenile) from the Black Sea and $5200 \mathrm{ng} / \mathrm{g}$ lw for male porpoises (adult and juvenile) from Hokkaido (Japan). Results from the pres- ent study were about 10-15 times higher than concentrations from Hokkaido, however, they were lower than levels reported for male porpoises from the Black Sea in 1993 indicating that DDX concentrations decreased slightly in a 5 year period.

MeO-PBDEs and PBHDs have been suggested to be produced by marine organisms, such as algae and sponges (Vetter et al., 2002; Malmvärn et al., 2008). These compounds have been reported previously in whale and fish oil (Teuten and Reddy, 2007; Covaci et al., 2007), in fish and in marine mammals (Vetter et al., 2002; Pettersson et al., 2004; Melcher et al., 2005; Losada et al., 2009; Weijs et al., 2009b). To date, no reports on their presence of algae and sponges in the Black Sea are available. Among MeO-PBDEs, 6$\mathrm{MeO}-\mathrm{BDE} 47$ was the most dominant compound, as indicated for marine mammals from the Northern hemisphere in general (Weijs et al., 2009b). Although not statistically significant, adults had lower concentrations of sum MeO-PBDEs compared to the juveniles, suggesting that they are more capable of metabolic breakdown or elimination of these naturally-produced compounds than juveniles or that the juveniles have a high 'start' concentration due to maternal placental transfer to offspring. This finding was also reported for adult male and juvenile male harbour seals and porpoises from the North Sea (Weijs et al., 2009b). Concentrations of MeO-PBDEs were lower compared to those in cetaceans from Canada, Japan, Australia and Europe (Kelly et al., 2008; Marsh et al., 2005; Melcher et al., 2005; Weijs et al., 2009b), but higher than concentrations in pinnipeds from Canada and Europe (Kelly et al., 
2008; Weijs et al., 2009b) (Table 2). Tri-BHD (2,7-dibromo-4a-bromomethyl-1,1-dimethyl-2,3,4,4a,9,9a-hexahydro-1H-xanthene) had the highest concentration among all naturally-produced compounds. Concentrations of sum PBHDs were more than 10 times higher than concentrations in blubber of harbour porpoises from the North Sea (Weijs et al., 2009b). Except for kidney, concentrations were higher (only statistically significant for blubber) with age, again indicating bioaccumulation over time or a reduced metabolism with age.

For both age-groups, sum DDXs $>$ sum $\mathrm{PCBs}>\mathrm{HCB}>$ sum naturally-produced organobromines $>$ sum PBDEs for kidney, brain and liver. For muscle and blubber, the contribution of sum naturally-produced organobromines was higher compared to $\mathrm{HCB}$ (Fig. 3). A higher presence of DDXs compared to PCBs was reported previously for harbour porpoises from the Black Sea, being different from the North Sea (Tanabe et al., 1997b). To check for possible relationships between the concentrations of sum PCBs, sum PBDEs, sum DDXs, sum naturally-produced organobromines and HCB and the feeding ecology (assessed through stable isotope analyses, $\delta^{13} \mathrm{C}$ and $\delta^{15} \mathrm{~N}$ ), correlations were established. Measurements of $\delta^{13} \mathrm{C}$ and $\delta^{15} \mathrm{~N}$ in muscle of 17 out of 20 harbour porpoises (reported by Das et al., 2003, 2004) were used to investigate the influence of trophic position on the levels of the organohalogenated compounds in the present study. However, none of these correlations were significant (Spearman; all $p>0.05$ ).

Table 2

Inter-species comparison for MeO-PBDEs (sum of 2'-MeO-BDE 68 and 6-MeO-BDE 47). All concentrations are expressed in ng/g lipid weight (lw).

\begin{tabular}{|c|c|c|c|}
\hline Species & Tissue & $\begin{array}{l}\text { Concentration (ng/ } \\
\mathrm{g} l w)\end{array}$ & Reference \\
\hline $\begin{array}{l}\text { Ringed seal } \\
\text { Beluga whale }^{\mathrm{a}}\end{array}$ & $\begin{array}{l}\text { Blubber } \\
\text { Blubber } \\
\text { Liver }\end{array}$ & $\begin{array}{l}6.3 \\
298 \\
302\end{array}$ & Kelly et al. (2008) \\
\hline Striped dolphin & $\begin{array}{l}\text { Fresh } \\
\text { blubber } \\
\text { Cooked liver }\end{array}$ & $\begin{array}{l}52 \\
540\end{array}$ & $\begin{array}{l}\text { Marsh et al. } \\
(2005)\end{array}$ \\
\hline $\begin{array}{r}\text { Bottlenose } \\
\text { dolphin }\end{array}$ & Sliced bacon & 2910 & \\
\hline Minke whale & $\begin{array}{l}\text { Fresh } \\
\text { blubber }\end{array}$ & 48 & \\
\hline $\begin{array}{l}\text { Baird's beaked } \\
\text { whale }\end{array}$ & $\begin{array}{l}\text { Shredded } \\
\text { bacon }\end{array}$ & 58 & \\
\hline Common dolphin & Blubber & 5435 & $\begin{array}{l}\text { Melcher et al. } \\
\text { (2005) }\end{array}$ \\
\hline $\begin{array}{r}\text { Bottlenose } \\
\text { dolphin }\end{array}$ & Blubber & 13,145 & \\
\hline Melonhead whale & Blubber & 2005 & \\
\hline $\begin{array}{l}\text { Pygmy sperm } \\
\text { whale }\end{array}$ & Blubber & 2888 & \\
\hline \multirow{2}{*}{$\begin{array}{c}\text { Humpback } \\
\text { dolphin }\end{array}$} & Blubber & 2795 & \\
\hline & Brain & 151 & \\
\hline $\begin{array}{l}\text { Harbour } \\
\text { porpoise }^{\mathrm{a}}\end{array}$ & Blubber & $113.7-143^{b}$ & $\begin{array}{l}\text { Weijs et al. } \\
\text { (2009) }\end{array}$ \\
\hline Harbour seal $^{\mathrm{a}}$ & Blubber & $3.2-7^{\mathrm{b}}$ & \\
\hline \multirow{2}{*}{$\begin{array}{l}\text { Harbour } \\
\text { porpoise }^{a}\end{array}$} & Kidney & $10.6-11.7^{\mathrm{b}}$ & Present study \\
\hline & $\begin{array}{l}\text { Brain } \\
\text { Liver } \\
\text { Muscle } \\
\text { Blubber }\end{array}$ & $\begin{array}{l}2.3-3.1^{\mathrm{b}} \\
18.2-21.7^{\mathrm{b}} \\
39.0-45.7^{\mathrm{b}} \\
46.6-52.9^{\mathrm{b}}\end{array}$ & \\
\hline
\end{tabular}

Harbour porpoise - Phocoena phocoena; harbour seal - Phoca vitulina; humpback dolphin - Sousa chinensis; bottlenose dolphin - Tursiops truncatus; ringed seal Phoca hispida; Beluga whale - Delphinapterus leucas; common dolphin - Delphinus delphis; striped dolphin - Stenella coeruleoalba; minke whale - Balaenoptera acutorostrata; Baird's beaked whale - Berardius bairdii; melonhead whale - Peponocephala electra; pygmy sperm whale - Kogia breviceps.

a Only results from males.

b Concentration in adult males - concentration in juvenile males (values are medians).

\section{Conclusions}

The Black Sea is a region that is linked to the Mediterranean only through the Marmara Sea and thus the exchange of seawater is limited. This means that the input of anthropogenic pollutants in the Black Sea is largely influenced by the run-off from the surrounding countries. Harbour porpoises from the Black Sea spend their entire life in this area and are exposed to a typical mixture of pollutants. To our knowledge, the present study is the first to characterize the presence of anthropogenic PBDEs and naturallyproduced compounds (MeO-PBDEs and PBHDs) in tissues of adult and juvenile male harbour porpoises sampled in 1998 from the Black Sea. Profiles and levels of anthropogenic and naturally-produced compounds varied with age and between different tissues. However, our results show that concentrations of PBDEs were low, indicating that PBDEs were not commonly used in the 1990s in the countries surrounding the Black Sea. In contrast, DDXs and especially $p, p^{\prime}$-DDE, were dominant in the overall profiles in all tissues, suggesting that DDT was still used at least in some countries around the Black Sea.

\section{Acknowledgements}

Liesbeth Weijs acknowledges financial support from the Institute for the Promotion of Innovation through Science and Technology in Flanders (IWT-Flanders). Adrian Covaci is financially supported by a postdoctoral fellowship from the Research Scientific Foundation - Flanders (FWO). Krishna Das is a F.R.S.-FNRS Research Associate. The authors wish to thank Ursula Siebert, Alexei Birkun and Ludo Holsbeek for performing the necropsies and for providing the samples.

\section{References}

Agency for Toxic Substances and Disease Registry (ATSDR), 2001. Polychlorinated Biphenyls. US Department of Health and Human Services. <http:// www.atsdr.cdc.gov/toxfaq.html>.

Agency for Toxic Substances and Disease Registry (ATSDR), 2004. Polybrominated Diphenyl Ethers. US Department of Health and Human Services. <http:// www.atsdr.cdc.gov/toxfaq.html>.

Agency for Toxic Substances and Disease Registry (ATSDR), 2002. DDT, DDE, and DDD. US Department of Health and Human Services. <http:// www.atsdr.cdc.gov/toxfaq.html>.

Berge, J.A., Brevik, E.M., Bjørge, A., Følsvik, N., Gabrielsen, G.W., Wolkers, H., 2004 Organotins in marine mammals and seabirds from Norwegian territory. Journal of Environmental Monitoring 6, 108-112.

Bernhoft, A., Skaare, J.U., 1994. Levels of selected individual polychlorinated biphenyls in different tissues of harbour seals (Phoca vitulina) from the Southern coast of Norway. Environmental Pollution 86, 99-107.

Birkun, Jr., A.A., 2003. Dolphins and porpoises in the Black Sea: an overview of ecological and conservation aspects. Documents of the 55th Meet. IWC Scientific Committee (Berlin, 26 May - 6 June 2003). IWC, SC/55/SM16, 9p.

Birnbaum, L.S., Staskal, D.F., 2004. Brominated flame retardants: cause for concern? Environmental Health Perspectives 112, 9-17.

Boon, J.P., Lewis, W.E., Tjoen-A-Choy, M.R., Allchin, C.R., Law, R.J., De Boer, J., Ten Hallers-Tjabbes, C.C., Zegers, B.N., 2002. Levels of polybrominated diphenyl ether (PBDE) flame retardants in animals representing different trophic levels of the North Sea food web. Environmental Science and Technology 36, 4025-4032.

Borgå, K., Fisk, A.T., Hoekstra, P.F., Muir, D.C.G., 2004. Biological and chemical factors of importance in the bioaccumulation and trophic transfer of persistent organochlorine contaminants in Arctic marine food webs. Environmental Toxicology and Chemistry 23, 2367-2385.

Burreau, S., Zebühr, Y., Broman, D., Ishaq, R., 2006. Biomagnification of PBDEs and PCBs in food webs from the Baltic Sea and the northern Atlantic Ocean. Science of the Total Environment 366, 659-672.

Covaci, A., Van de Vijver, K.I., De Coen, W., Das, K., Bouquegneau, J.M., Blust, R., Schepens, P., 2002. Determination of organohalogenated contaminants in liver of harbour porpoises (Phocoena phocoena) stranded on the Belgian North Sea coast. Marine Pollution Bulletin 44, 1156-1165.

Covaci, A., Voorspoels, S., Vetter, W., Gelbin, A., Jorens, P.G., Blust, R., Neels, H., 2007. Anthropogenic and naturally occurring organobrominated compounds in fish oil dietary supplements. Environmental Science and Technology 41, 52375244.

Covaci, A., Losada, S., Roosens, L., Vetter, W., Santos, F.J., Neels, H., Storelli, A., Storelli, M.M., 2008. Anthropogenic and naturally-occurring organobrominated 
compounds in two deep-sea fish species from the Mediterranean Sea. Environmental Science and Technology 42, 8654-8660.

Das, K., Lepoint, G., Leroy, Y., Bouquegneau, J.M., 2003. Marine mammals from the southern North Sea : feeding ecology data from $\delta^{13} \mathrm{C}$ and $\delta^{15} \mathrm{~N}$ measurements. Marine Ecology Progress Series 263, 287-298.

Das, K., Holsbeek, L., Browning, J., Siebert, U., Birkin Jr, A., Bouquegneau, J.M., 2004. Trace metal and stable isotope measurements $\left(\delta^{13} \mathrm{C}\right.$ and $\left.\delta^{15} \mathrm{~N}\right)$ in the harbour porpoise Phocoena phocoena relicta from the Black Sea. Environmental Pollution 131, 197-204.

Debier, C., Pomeroy, P.P., Dupont, C., Joiris, C., Comblin, V., Le Boulengé, E., Larondelle, Y., Thomé, J.P., 2003a. Quantitative dynamics of PCB transfer from mother to pup during lactation in UK grey seals Halichoerus grypus. Marine Ecology Progress Series 247, 237-248.

Debier, C., Pomeroy, P.P., Dupont, C., Joiris, C., Comblin, V., Le Boulengé, E., Larondelle, Y., Thomé, J.P., 2003b. Dynamics of PCB transfer from mother to pup during lactation in UK grey seals Halichoerus grypus: differences in PCB profile between compartments of transfer and changes during the lactation period. Marine Ecology Progress Series 247, 249-256.

Duinker, J.C., Hillebrand, M.T.J., Zeinstra, T., Boon, J.P., 1989. Individual chlorinated biphenyls and pesticides in tissues of some cetacean species from the North Sea and the Atlantic Ocean; tissue distribution and biotransformation. Aquatic Mammals 15, 95-124.

Fillmann, G., Readman, J.W., Tolosa, I., Bartocci, J., Villeneuve, J.P., Cattini, C., Mee L.D., 2002. Persistent organochlorine residues in sediments from the Black Sea. Marine Pollution Bulletin 44, 122-133.

Fontaine, M.C., Baird, S.J.E., Piry, S., Ray, N., Tolley, K.A., Duke, A., Birkun Jr, A Ferreira, M., Jauniaux, T., Llavona, A., Öztürk, B., Öztürk, A., Ridoux, V., Rogan, E. Sequeira, M., Siebert, U., Vikingsson, G.A., Bouquegneau, J.M., Michaux, J.R. 2007. Rise of oceanographic barriers in continuous populations of a cetacean: the genetic structure of harbour porpoises in Old World waters. BMC Biology 5 , 30.

Hoekstra, P.F., O’Hara, T.M., Fisk, A.T., Borgå, K., Solomon, K.R., Muir, D.C.G., 2003. Trophic transfer of persistent organochlorine contaminants (OCs) within an Arctic marine food web from the southern Beaufort-Chukchi Seas. Environmental Pollution 124, 509-522.

Ikonomou, M.G., Addison, R.F., 2008. Polybrominated diphenyl ethers (PBDEs) in seal populations from eastern and western Canada: an assessment of the processes and factors controlling PBDE distribution in seals. Marine Environmental Research 66, 225-230.

Johnson-Restrepo, B., Kannan, K., Addink, R., Adams, D.H., 2005. Polybrominate diphenyl ethers and polychlorinated biphenyls in a marine food web of coastal Florida. Environmental Science and Technology 39, 8243-8250.

Joiris, C.R., Holsbeek, L., Bolba, D., Gascard, C., Stanev, T., Komakhidze, A Baumgärtner, W., Birkun, A., 2001. Total and organic mercury in the Black Sea harbour porpoises Phocoena phocoena relicta. Marine Pollution Bulletin 42, 905911.

Kannan, K., Falandysz, J., Tanabe, S., Tatsukawa, R., 1993. Persistent organochlorine in harbour porpoises from Puck Bay, Poland. Marine Pollution Bulletin 26, 162 165.

Kelly, B.C., Ikonomou, M.G., Blair, J.D., Gobas, F.A.P.C., 2008. Hydroxylated and methoxylated polybrominated diphenyl ethers in a Canadian Arctic marine food web. Environmental Science and Technology 42, 7069-7077.

Losada, S., Roach, A., Roosens, L., Santos, F.J., Galceran, M.T., Vetter, W., Neels, H. Covaci, A., 2009. Biomagnification of anthropogenic and naturally-produced organobrominated compounds in a marine food web from Sydney Harbour. Australia. Environment International 35, 1142-1149.

Madhusree, B., Tanabe, S., Ozturk, A.A., Tatsukawa, R., Miyazaki, N., Ozdamar, E. Aral, O. Samsun, O., Ozturk, B., 1997. Contamination by butyltin compounds in harbour porpoise (Phocoena phocoena) from the Black Sea. Fresenius Journal of Analytical Chemistry 359, 244-248.

Malmvärn, A., Zebühr, Y., Kautsky, L., Bergman, Å, Asplund, L., 2008. Hydroxylated and methoxylated polybrominated diphenyl ethers and polybrominated dibenzo-p-dioxins in red alga and cyanobacteria living in the Baltic Sea. Chemosphere 72, 910-916.

Marsh, G., Athanasiadou, M., Athanassiadis, I., Bergman, A., Endo, T., Haraguchi, K. 2005. Identification, quantification and synthesis of a novel dimethoxylated polybrominated biphenyl in marine mammals caught off the coast of Japan. Environmental Science and Technology 22, 8684-8690.

Melcher, J., Olbrich, D., Marsh, G., Nikiforov, V., Gaus, C., Gaul, S., Vetter, W., 2005 Tetra- and tribromophenoxyanisoles in marine samples from Oceania. Environmental Science and Technology 39, 7784-7789.
Melcher, J., Janussen, D., Garson, M.J., Hiebl, J., Vetter, W., 2007. Polybrominated hexahydroxanthene derivatives (PBHDs) and other halogenated natural products from the Mediterranean sponge Scalarispongia scalaris in marine biota. Archives of Environmental Contamination and Toxicology 52, 512-518.

Montie, E.W., Reddy, C.M., Gebbink, W.A., Touhey, K.E., Hahn, M.E., Letcher, R.J., 2009. Organohalogen contaminants and metabolites in cerebrospinal fluid and cerebellum gray matter in short-beaked common dolphins and Atlantic whitesided dolphins from the western North Atlantic. Environmental Pollution 157, 2345-2358.

Pena-Abaurrea, M., Weijs, L., Ramos, L., Borghesi, N., Corsolini, S., Neels, H., Blust, R., Covaci, A., 2009. Anthropogenic and naturally-produced organobrominated compounds in bluefin tuna from the Mediterranean Sea. Chemosphere 76, 1477-1482.

Pettersson, A., van Bavel, B., Engwall, M., Jimenez, B., 2004. Polybrominated diphenylethers and methoxylated tetrabromodiphenylethers in cetaceans from the Mediterranean Sea Archives of Environmental Contamination and Toxicology 47, 542-550.

Ruus, A., Ugland, K.I., Espeland, O., Skaare, J.U., 1999. Organochlorine contaminants in a local marine food chain from Jarfjord, Northern Norway. Marine Environmental Research 48, 131-146.

Shaw, S.D., Brenner, D., Berger, M.L., Fang, F., Hong, C.S., Addink, R., Hilker, D., 2008. Bioaccumulation of polybrominated diphenyl ethers in harbor seals from the northwest Atlantic. Chemosphere 73, 1773-1780.

Shaw, S.D., Berger, M.L., Brenner, D., Kannan, K., Lohmann, N., Päpke, O., 2009. Bioaccumulation of polybrominated diphenyl ethers and hexabromocyclododecane in the northwest Atlantic marine food web. Science of the Total Environment 407, 3323-3329.

Tanabe, S., Madhusree, B., Öztürk, A.A., Tatsukawa, R., Miyzaki, N., Özdamar, E., Aral, O., Samsun, O., Öztürk, B., 1997a. Isomer-specific analysis of polychlorinated biphenyls in harbour porpoise (Phocoena phocoena) from the Black Sea. Marine Pollution Bulletin 34, 712-720.

Tanabe, S., Madhusree, B., Öztürk, A.A., Tatsukawa, R., Miyzaki, N., Özdamar, E., Aral, O. Samsun, O., Öztürk, B. 1997b. Persistent organochlorine residues in harbour porpoise (Phocoena phocoena) from the Black Sea. Marine Pollution Bulletin 34, 338-347.

Teuten, E.L., Reddy, C.M., 2007. Halogenated organic compounds in archives whale oil: a pre-industrial record. Environmental Pollution 145, 668-671.

Thompson, A., Allen, J.R., Dodoo, D., Hunter, J., Hawkins, S.J., Wolff, G.A., 1996. Distribution of chlorinated biphenyls in mussels and sediments from Great Britain and the Irish Sea coast. Marine Pollution Bulletin 32, 232-237.

Tonay, A.M., Dede, A., Öztürk, A.A., Öztürk, B., 2007. Stomach content of harbour porpoises (Phocoena phocoena) from the Turkish Western Black Sea in spring and early summer. Rapport Commission Internationale pour l'Exploration Scientifique de la Mer Méditerranée 38, 616.

Vetter, W., Stoll, E., Garson, M.J., Fahey, S.J., Gaus, C., Müller, J.F., 2002. Sponge halogenated natural products found at parts-per-million levels in marine mammals. Environmental Toxicology and Chemistry 21, 2014-2019.

Viaud-Martinez, K.A., Martinez Vergara, M., Gol'din, P.E., Ridoux, V., Ozturk, A.A., Ozturk, B., Rosel, P.E., Frantzis, A., Komnenou, A., Bohonak, A.J., 2007. Morphological and genetic differentiation of the Black Sea harbour porpoise (Phocoena phocoena relicta). Marine Ecology Progress Series 338, 281-294.

Voorspoels, S., Covaci, A., Schepens, P., 2003. Polybrominated diphenyl ethers in marine species from the Belgian North Sea and the Western Scheldt Estuary: levels, profiles and distribution. Environmental Science and Technology 37, 4348-4357.

Voorspoels, S., Covaci, A., Maervoet, J., De Meester, I., Schepens, P., 2004. Levels and profiles of PCBs and OCPs in marine benthic species from the Belgian North Sea and the Western Scheldt Estuary. Marine Pollution Bulletin 49, 393-404.

Weijs, L., Dirtu, A.C., Das, K., Gheorghe, A., Reijnders, P.J.H., Neels, H., Blust, R., Covaci, A., 2009a. Inter-species differences for polychlorinated biphenyls and polybrominated diphenyl ethers in marine top predators from the Southern North Sea: part 1. Accumulation patterns in harbour seals and harbour porpoises. Environmental Pollution 157, 437-444.

Weijs, L., Losada, S., Das, K., Roosens, L., Reijnders, P.J.H., Neels, H., Blust, R., Covaci, A., 2009b. Biomagnification of naturally-produced methoxylated polybrominated diphenyl ethers (MeO-PBDEs) in harbour seals and harbour porpoises from the Southern North Sea. Environment International 35, 893899. 